\title{
Optimalisasi pendampingan belajar home learning di era pandemi covid-19 di Pantai Amal Kota Tarakan
}

\section{Nurmala $R$}

\author{
Pendidikan Matematika, FKIP, Universitas Borneo Tarakan, Tarakan
}

nurmala.r17@gmail.com

\begin{abstract}
The Home Learning program during the COVID-19 pandemic is a community service activity in the implementation of the tri dharma of higher education at the University of Borneo Tarakan. This service activity is carried out to increase learning motivation and student interest in learning at school. The impact of the COVID-19 pandemic is enormous in the education sector. The difficulties experienced by parents of students at Binalatung Pantai amal is when accompanying their children with inadequate facilities and abilities, one of which is that parents are busy in their daily activities to earn a living as fishermen and seaweed farmers. Therefore, to help the parents of these students also stay at home to decide the transmission of covid-19, we held a home learning program as a community service activity, and the objects were students in Binalatung. The learning mentoring method used is to provide offline learning assistance in the form of small groups consisting of 5 people in each study group. The mentoring process went well and smoothly. The results obtained from the study assistance at the charity beach binalatung are quite good. Students are very enthusiastic during the learning mentoring process and feel helped in completing assignments at school.
\end{abstract}

Keywords: learning assistance; home learning; covid-19 pandemic

\begin{abstract}
Abstrak
Program Home Learning di masa pandemi covid-19 ini merupakan kegiatan pengabdian kepada masyarakat dalam pelaksanaan tri dharma perguruan tinggi di Universitas Borneo Tarakan. Kegiatan pengabdian ini dilaksanakan untuk meningkatkan motivasi belajar serta minat belajar siswa terhadap pelajaran di sekolah. Dampak pandemi covid-19 sangat besar dalam sektor pendidikan. Kesulitan yang di alami orang tua siswa di Binalatung Pantai Amal adalah ketika mendampingi anak-anak mereka dengan fasilitas dan kemampuan yang kurang memadai, salah satunya orang tua sibuk dalam keiatan sehariharinya mencari nafkah sebagai nelayan dan petani rumpu laut. Oleh karena itu, untuk membantu orang tua siswa tersebut juga tetap dirumah saja untuk memutuskan penularan covid-19, kami mengadakan kegiatan program home learning sebagai kegiatan pengabdian kepada masyarakat, dan objeknya adalah siswa-siswa di Binalatung. Metode pendampingan belajar yang digunakan adalah dengan memberikan pendampingan belajar secara luring dalam bentuk kelompok kecil yang terdiri dari 5 orang setiap kelompok belajar. Proses pendampingan yang dilakukan berjalan dengan baik dan lancar. Hasil yang diperoleh dari pendampingan belajar di Binalatung Pantai Amal ini cukup bagus. Siswa sangat antusias selama proses pendampingan belajar dan merasa terbantu dalam menyelesaikan tugas di sekolah.
\end{abstract}

Kata Kunci: pendampingan belajar; home learning; pandemic covid-19

\section{PENDAHULUAN}

Dalam UUD 1945 pasal 31 ayat 1 menyatakan bahwa setiap warga negara berhak mendapatkan pendidikan. Mengingat arti sebuah pendidikan sangatlah penting bagi 
setiap manusia atas hak yang dimilikinya, pemberian pendidikan bagi seluruh warga haruslah diperhatikan dengan baik (Nadziroh et al., 2018). Pada hakikatnya pendidikan adalah hak dasar bagi setiap warga negara Indonesia untuk dapat menikmatinya. Pendidikan merupakan usaha sadar yang dilakukan oleh manusia agar dapat mengembangkan potensi dirinya melalui proses pembelajaran (Ambarningsih, 2014). Pendidikan diarahkan bagi seluruh warga sebagai prioritas utama agar dapat mengembangkan moral yang lebih baik yang akan memberikan pengaruh baik terhadap generasi penerus bangsa. Pendidikan merupakan suatu proses sistematis yang melibatkan faktor internal maupun eksternal. Faktor internal yang dimaksud tersebut adalah berasal dari dalam diri siswa contohnya: motivasi, minat belajar, bakat dan persepsi. Sedangkan untuk faktor eksternal yang dimaksud adalah datang dari luar diri siswa, seperti lingkungan belajar siswa, lingkungan keluarga, latar belakang sosial ekonomi keluarga dan perhatian orang tua dalam membantu mengatasi kesulitan belajar yang dialami anak (Komari, 2015). Pendidikan secara formal saja dirasa tidak cukup untuk meningkatkan pemahaman siswa dalam belajar, sehingga banyak yang menempuh pendidikan non-formal pada lembaga bimbingan belajar di luar jam belajar sekolah (Ari \& Ardhi, 2015).

Adanya pandemi Covid-19 yang melanda dunia termasuk Indonesia, berdampak pada berbagai aspek kehidupan salah satunya pendidikan. Maka lembaga pendidikan mengharuskan menjalankan proses kegiatan pembelajaran secara jarak jauh (Basar, A. M., Islam et al., 2021). Situasi pandemi Covid-19 berdampak sangat besar pada proses pembelajaran seperti siswa yang merasa jenuh dan bosan selama pelaksanaan kegiatan pembelajaran hal ini dikarenakan yang biasanya dilaksanakan secara langsung kini dialihkan menjadi pembelajaran daring sehingga proses pembelajaran dirasa kurang efektif (Putria et al., 2020). Satu kesulitan yang dialami oleh siswa saat ini berhubungan dengan situasi masa pandemic covid-19. Dalam situasi ini siswa diliburkan dalam pelaksanaam pembelajaran tatap muka, akan tetapi siswa dapat belajar secara online/pembelajaran daring dari rumah. Hal ini dilakukan oleh pemerintah dalam upaya memutus rantai covid-19, pemerintah membuat kebijakan untuk kegiatan pembelajaran dilakukan secara daring/online dimasa pandemi ini. Situasi yang seperti ini memberikan peluang permasalahan-permasalahan yang dialami siswa yaitu berkurangnya motivasi serta minat belajar siswa untuk mengikuti kegiatan pembelajaran, keterbatasan guru dalam menjelaskan materi sehingga siswa tidak paham. Kurangnya motivasi serta minat belajar siswa untuk mengikuti kegiatan pembelajar muncul akibat pembelajaran daring ini. Keterbatasan hubungan guru dalam menjelaskan materi membuat siswa tidak paham serta ketidaksanggupan orang tua dalam membimbing proses belajar anaknya menjadi kendala dalam pembelajaran daring (Handayani et al., 2020). Selain itu, ketidaksanggupan dan kurangnya kemampuan orang tua dalam membimbing proses belajar anaknya menjadi kendala dalam pembelajaran daring.

Dampak dari langkah-langkah pencegahan penyebaran virus covid-19 yang dipilih oleh pemerintah tersebar secara merata ke dalam berbagai sektor, seperti ekonomi, industri, pariwisata, bahkan Pendidikan (Santoso \& Rusmawati, 2019). Sejak penyebaran virus ini semakin meningkat, tempat fasilitas umum yang menjadi tempat orang-orang dapat 
berkerumun termasuk lembaga pendidikan ditutup oleh pemerintah demi mencegah penyebaran virus ini. Akibatnya, semua siswa terpaksa meliburkan diri dengan kewajiban belajar dirumah masing- masing dengan pendampingan orang tua. Akan tetapi, tidak semua orang tua menyadari dan memahami sistem wajib belajar di rumah, sehingga anak-anak mereka seakan menikmati liburan yang diselenggarakan pemerintah dan para guru, padahal guru telah memberikan setumpuk tugas untuk para siswa belajar di rumah sebagai pengganti pelajaran di sekolah. Kurangnya wawasan dalam pembelajaran daring dapat diatasi dengan pendampingan belajar siswa. Pendampingan belajar merupakan upaya membantu individu maupun kelompok oleh seorang atau lebih pembimbing yang memiliki keahlian di bidang tertentu dalam menentukan pilihan, penyesuaian serta pemecahan masalah belajar (Rosaria \& Novika, 2017).

Melihat kondisi tersebut, harus ada pergerakan yang dapat membantu agar siswa tetap menerima haknya dalam belajar meskipun sekolah diliburkan dalam tatap muka dengan mengganti pembelajaran secara daring. Dengan melihat kondisi dan situasi yang dialami di daerah Binalatung Pantai Amal yang masih terbilang aman untuk melakukan kegiatan dlam interaksi social tanpa menyalahi protocol kesehatan menggunakan masker, menerapkan social distancing dan lain-lain.

Program home learning ini dilakukan secara berkelompok, dan bergantian dengan kelompok lain di tempat dan waktu yang telah disepakati bersama dan kami berharap para siswa yang libur sekolah tetap mendapatkan pengetahuan sesuai tingkat dan kemampuan masing-masing siswa. Hal ini juga diharapkan dapat membantu para guru dan orang tua untuk mengondisikan siswa belajar di rumah dan memanfaatkan waktu selama masa Pandemi Covid-19.

\section{METODE PELAKSANAAN}

Metode pendampingan belajar yang digunakan untuk menyelesaikan permasalahan yang terjadi di Kawasan Binalatung Pantai Amal adalah dengan memberikan pendampingan belajar secara luring dengan program home learning, yaitu melaksanakan proses belajar mengajar secara langsung dan tatap muka. Pendampingan belajar ini dilakukan dalam kelompok kecil yang terdiri dari 3-5 orang. Bentuk pengabdian melalui pendampingan belajar ini pernah dilakukan oleh (Agustina et al., 2019) yang dilakukan selama 1 bulan. Hasil kegiatan pengabdian pada masyarakat tersebut mendapat sambutan positif dari pihak sekolah, terutama karena pelatihan ini sesuai dengan kebutuhan mereka dan motivasi peserta pelatihan cukup antusiasPendampingan belajar berlokasi di daerah Binalatung Pantai Amal dengan memanfaatkan menggunakan mushollah yang ada di daerah tersebut. Sehingga memudahkan siswa dalam belajar karena tempat belajar dengan tempat tingga mereka tidak jauh. 
Kegiatan pengabdian ini dilakukan dalam beberapa tahap, yaitu tahap persiapan, pelaksanaan, dan evaluasi.

1. Tahap Persiapan

Tahap persiapan dimulai dengan mengurus surat izin kepada kelurahan dan RT setempat yang merupakan tempat dilaksanakan kegiatan pengabdian kepada masyarakat. Dalam kegiatan persiapan juga dilakukan koordinasi tim terkait kegiatan pengabdian.

2. Tahap Pelaksanaan

Tahap berikutnya adalah pelaksanaan, kegiatan pengabdian kepada masyarakat ini dilaksanakan pada bulan Oktober-Desember 2020 di Binalatung Pantai Amal. Pendampingan belajar ini dilakukan dalam kelompok kecil yang terdiri dari 3-5 orang anak. Teknik pelaksanaan kegiatan home learning dengan pendampingan belajar yaitu dilaksanakan dengan menyampaikan materi terlebih dahulu dan mendampingi anak dalam mengerjakan Latihan soal dan dilanjutkan pembimbingan mengerjakan tugas belajar dari sekolah.

3. Tahap Sosialisai

Pada tahap sosialisasi ini dilakukan dengan mensosialisasikan kepada orang tua siswa dengan menyampaikan bagaimana mendampingi anak dalam menjalani kegiatan belajar dari rumah selama masa pembelajaran daring/online. Kegiatan sosialisasi ini dilakukan dengan harapan agar orang tua dapat mendampingi secara mandir anak-anaknya di rumah, sehingga siswa juga dapat belajar di rumah dengan nyaman dengan tetap didampingi dan dikontrol oleh orang tua.

4. Tahap Evaluasi

Tahap selanjutnya adalah evaluasi. Tahapan ini dilaksanakan untuk melihat perkembangan program yang dilaksanakan dan kebermanfaatan dari kegiatan ini selama berlangsung. Evaluasi bertujuan untuk melihat dan mengetahui kendala yang terjadi di lapangan serta cara menanganinya, sehingga program pengabdian yang dilakukan benar-benar efektif dan maksimal.

\section{HASIL DAN PEMBAHASAN}

Kegiatan pendampingan belajar home learning pada masa pandemi covid-19 merupakan pelaksanaan tri dharma perguruan tinggi yaitu pengabdian kepada masyarakat. Kegiatan ini dilaksanakan di Binalatung Pantai Amal Kota Tarakan dengan tujuan untuk membantu orang tua siswa membimbing dan mendapingi siswa dalam belajar selama masa pandemic covid-19 serta dapat meningkatkan motivasi belajar dan minat belajar siswa dalam menghadapi pembelajaran daring. Selain itu, dengan adanya kegiatan ini dapat membantu permasalahan-permasalahan yang terjadi pada siswa.

Kegiatan pendampingan belajar home learning dilaksanakan disebabkan melihat kondisi saat ini bahwa selama pembelajaran daring, kebanyakan siswa mengalami hambatan. Perjalanan pembelajaran daring ini menuntut siswa untuk terbiasa dengan hal tersebut begitupula dengan orang tua dituntut untuk selalu siaga dalam 
mendampingi anak-anaknya dalam mengikuti pembelajaran daring. Pembelajaran daring membuat siswa bosan karena tidak dapat bertemu dengan teman-teman (Handayani et al., 2020). Belajar bersama teman-teman lebih menyenangkan daripada belajar sendirian di rumah. Begitu juga guru, dalam pembelajaran daring, guru mempunyai keterbatasan ruang dalam menyampaikan dan menjelaskan materi. Kondisi ini menjadikan siswa merasa tidak paham dengan materi yang disampaikan. Meskipun ada orang tua di rumah di rumah, namun tidak semua siswa dapat dibimbing oleh orang tuanya setiap waktu dalam belajar, salah satunya karena orang tua yang sibuk bekerja.

Pendampingan belajar siswa ini dilakukan dengan membagi kedalam beberapa kelompok kecil terdiri dari 3-5 orang setiap kelompok. Dalam hasil penelitian sebelumnya, menyatakan bahwa motivasi belajar siswa underachiever dapat ditingkatkan melalui layanan bimbingan kelompok yang tepat. Sehingga, dengan pembagian kelompok belajar ini, dihrapkan siswa dapat meningkatkan motivasi belajar siswa dan prestasi belajr siswa (Zomaroh A.Khasanah., 2013). Dalam pelaksanaannya dilakukan setiap hari sabtu dengan dua sesi secara bergantin. Dalam pelaksanaan kegiatan bimbingan belajar home learning ini dimulai dengan berdoa dengan tujuan agar menumbuhkan sifat pada siswa untuk selalu melibatkan tuhan dalam kehidupan sehari-hari termasuk kegiatan pembelajaran, sehingga diberikan kemudahan-kemudahan dalam memahami materi pembelajaran yang diberikan oleh guru. Selanjutnya setelah kegiatan berdoa dilakukan, diberikan motivasi siswa agar membangkitkan semangat beljar siswa dalam menghadapi pembelajaran. Dalam memotivasi siswa ini, senantiasa diawali dengan cerita-cerita tokoh inspiratif agar dapat menjadi motivasi bagi siswa untuk menjadi lebih daripada cerita tokoh tersebut. Selain itu, juga diberikan kata-kata penyemangat berupa kata-kata mutiara yang dapat diambil sebagai pegangan atau pembelajaran dalam kehidupan sehari-hari.

Sebelum kegiatan pembimbingan belajar dimulai, menyampaikan materi terlebih dahulu dengan metode pembelajaran kooperatif, metode demonstrasi dan metode ceramah. Dengan metode bervariasi suasana belajar juga tidak monoton sehingga siswa selalu antusias dalam mengikuti kegiatan home learning. Setelah itu dilakukan pembimbingan dan pendampingan kepada siswa dalam memahami materi. Dalam rangkaian kegiatan ini, juga diberikan kesempatan untuk melakukan tanya jawab dimana siswa diberi kesempatan untuk bertanya agar dapat melihat sampai mana kemampuan siswa dalam memahami materi, begitupula sebaliknya. Siswa yang dapat menyelesaikan soal latihan yang dberikan, akan diberikan reward berupa barang yang dapat digunakan dalam proses belajar siswa seperti alat tulis ataupun buku bacaan. Pemberian reward ini memberikan kontribusi dalam meningkatkan motivasi belajar siswa. Hal ini sejalan dengan hasil penelitian yang dilakukan oleh Itsnaini Fadlilah bahwa pemberian reward berpengaruh signifikan terhadap motivasi dan hasil belajar kognitif siswa (Istnaini, 2019). 

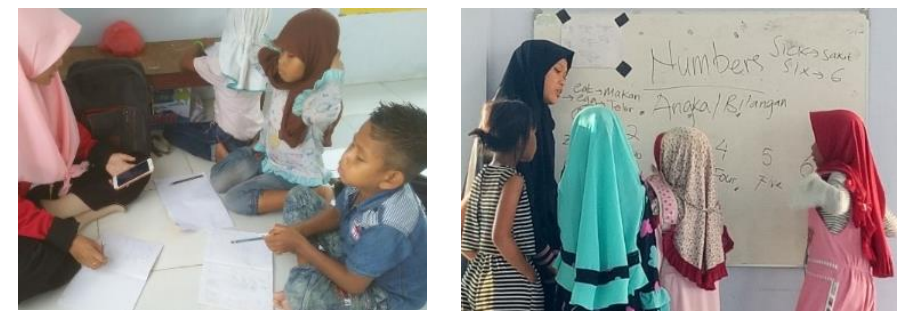

\section{Gambar 1. Kegiatan pendampingan belajar home learning siswa di Binalatung}

Kegitan pendampingan siswa ini, selain mendampingi siswa dalam belajar juga diberikan games permainan kepada siswa agar siswa tidak bosan dalam meneima pelajaran. Games yang diberikan masih berkaitan dengan materi pelajaran. Games merupakan salah satu sarana untuk meningkatkan perkembangan otak dan saraf motorik anak dengan cara yang santai dan menyenangkan (Eliska, 2018). Selain itu, Games atau permainan merupakan salah satu sarana yang bisa dijadikan sebagai jalan untuk melakukan transportasi ilmu kepada anak-anak (Nisak, 2014). Pada masa sekarang ini dalam sebuah sistem pendidikan modern, fungsi guru sebagai penyampai pesan pendidikan tampaknya memang sangat perlu dibantu dengan media pembelajaran, seperti cerita dan games agar proses pembelajaran dapat berjalan secara efektif dan juga dapt memotivasi minat anak untuk belajar (Ratnawati \& Asniawati, 2020). Dalam pelaksanaannya terlihat siswa antusias dalam mengikuti kegiatan ini sehingga siswa-siswa kembali bersemangat dalam mengikuti pembelajaran.

Di akhir kegiatan diberikan post test untuk mengukur sejauh mana kemampuan siswa selama mengikuti kegiatan pendampingan belajar. Hasil post test menunjukkan bahwa siswa dapat memahami materi yang disampaikan dengan baik dengan rata-rata nilai 74,4. Sehingga perkembangan kognitif dan motivasi siswa slama mengikuti kegiatan pendampingan belajar home learning dapat dikatakan mengalami perkembangan dengan baik, dengan melihat dokumentasi keseharian siswa dalam mengikuti kegiatan begitupula dengan tugas, test akhir yang diberikan, dan hasil diskusi wawancara dari sisswa dan orang tua siswa.

\section{SIMPULAN}

Program Home Learning di masa pandemi covid-19 ini merupakan kegiatan pengabdian kepada masyarakat dalam pelaksanaan tri dharma perguruan tinggi di Universitas Borneo Tarakan. Kegiatan ini diikuti oleh siswa-siswa yang ada di Kawasan Binalatung Pantai Amal Kota Tarakan. Proses pendampingan belajar yang dilakukan berjalan dengan baik dan lancer, hal ini ditunjukkan dengan terlihat siswa sangat antusias selama proses kegiatan pendampingan belajar berlangsung dan siswa merasa terbantu dalam menyelesaikan tugas di sekolah begitupula dengan 
orang tua siswa yang merasa terbantu dalam mendampingi anak-anaknya dalam mengikuti pembelajaran daring.

\section{UCAPAN TERIMA KASIH}

Ucapan terima kasih yang sebesar-besar disampaikan kepada pemerintah kelurahan Pantai Amal atas izin pelaksanaan kegiatan pengabdian kepada Tim Pengabdian Masyarakat Universitas Borneo Tarakan. Terima kasih juga kami sampaikan kepada Ketua RT 14 dan warga/ orang tua kelurahan pantai amal atas dukungan dan bantuan selama kegiatan pengabdian berjalan.

\section{REKOMENDASI}

Kegiatan pendampingan belajar dengan metode Home Learning merupakan kegiatan yang sangat bermanfaat buat anak-anak di masa pandemi covid-19 di kelurahan pantai amal. Karena dengan kegiatan ini, membantu anak-anak dalam belajar secara mandiri di rumah dan juga membantu orang tua dalam menjelaskan matri pembelajaran sekolah yang belum tentu orang tuanya mengerti. Untuk kedepannya sangat diharapkan diadakan kegiatan serupa yang dapat membantu siswa dan orang tua dalam menguasai materi pembelajaran di sekolah. Sehingga siswa yang belajar secara online dirumah tidak merasa bosan dan tetap semangat mempelajari pelajarannya meski di masa pandemi covid-19.

\section{REFERENSI}

Agustina, E., Rohmah, A., \& Kuspiyah, H. (2019). Pendampingan Bimbingan Belajar Bahasa Inggris dan Bakti Sosial di Yayasan Pendidikan dan Sosial Roudlotut Thullab. Indonesia Mengabdi, 1(1), 1-5.

Ambarningsih, D. (2014). Peningkatan Hasil Belajar Menulis Puisi Bebas Melalui Metode Suggestopedia. Journal of Elementary Education, 3(2).

Ari, S. P. M., \& Ardhi, W. (2015). Analisis Kepuasan Siswa Terhadap Kegiatan Pembelajaran Biologi Pada Sekolah Formal Dan Lembaga Bimbingan Belajar Non-Formal Di Kota Madiun. Jurnal Penelitian LPPM IKIP PGRI Madiun, 3(1), 1-5.

Basar, A. M., Islam, P. A., Nurul, S., Cikarang, F., \& Bekasi, B. (2021). Problematika Pembelajaran Jarak Jauh Pada Masa Pandemi Covid-19 ( Studi Kasus di SMPIT Nurul Fajri - Cikarang Barat -Bekasi ). Jurnal Ilmiah Pendidikan, 2(1), 208-218.

Eliska, N. (2018). Pengaruh Pemberian Games Pembuka Dan Penutup Pembelajaran Terhadap Motivasi Belajar Pada Mata Pelajaran Pendidikan Kewarganegaraan Murid Kelas V SDN 05 Tokkene Kecamatan Tanete Riaja Kabupaten Barru.

Handayani, T., HN, K., \& R., Y. (2020). Pendampingan Belajar Di Rumah Bagi Siswa Sekolah Dasar Terdampak Covid-19. ABDIPRAJA (J.Pengabdi. Kpd. Masyarakat), 1(2).

Istnaini, F. (2019). Pengaruh Reward terhadap Motivasi dan Hasil Belajar Kognitif Siswa Kelas IV di SDN 1 Karangan. Jurnal Pendidikan Dasar Nusantara, 5(1).

Komari, N. (2015). Pengaruh Tingkat Pendidikan Perhatian Orang Tua, Dan MinatBelajar Siswa Terhadap Prestasi Belajar Bahasa Indonesia Siswa Smk Kesehatan Di Kota 
Tangerang. Jurnal Pujangga, 1(2).

Nadziroh, Chairiyah, \& Pratomo, W. (2018). Hak Warga Negara Dalam Memperoleh Pendidikan Dasar Di Indonesia. Jurnal Pendidikan Ke-SD-An, 4(3), 400-405.

Nisak, R. (2014). Seabrek Game Asyik Edukatif untuk Mengajar PAUD/TK. Yogyakarta: Diva Press.

Putria, H., Maula, M., \& Uswatun, D. (2020). nalisis Proses pembelajaran Dalam Jaringan (DARING) Masa Pandemi COVID-19 pada Guru Sekolah Dasar. Jurnal Basicedu, 4(1).

Ratnawati, E., \& Asniawati, A. (2020). Pemberian Motivasi Melalui Cerita Dan Games Untuk Menumbuhkan Minat Belajar Anak Usia SD Dan SMP. Jurnal Pengabdian DIMASEJATI, $2(2)$.

Rosaria, D., \& Novika, H. (2017). Bimbingan Belajar Bahasa InggrisBagi Anak Usia Sekolah Dasar (612 Tahun) Di Desa Semangat Dalam Rt.31 handil Bhakti. Jurnal Al-Ikhlas, 2(2).

Santoso, A., \& Rusmawati, Y. (2019). Pendampingan Belajar Siswa di Rumah Melalui Kegiatan Bimbingan Belajar di Desa Guci Karanggeneng Lamongan. Abdimas Berdaya: Jurnal Pengabdian Masyarakat, 2(2), 36-43.

Zomaroh A.Khasanah. (2013). Meningkatkan Motivasi Belajar Siswa Underachiever Melalui Layanan Bimbingan Kelompok pada Siswa SD Negeri Pekunden Semarang. Universitas Negeri Semarang. 